\title{
Numerical Modeling of Changes In Groundwater Storage And Nitrate Load in The Unconfined Aquifer Near a River Receiving Reclaimed Water
}

Ruixue Jiang ( $\sim$ ruixue_jiang@163.com )

Institute of Geographic Sciences and Natural Resources Research Chinese Academy of Sciences https://orcid.org/0000-0003-3469-1842

Dongmei Han

Institute of Geographic Sciences and Natural Resources Research Chinese Academy of Sciences

\section{Xianfang Song}

Institute of Geographic Sciences and Natural Resources Research Chinese Academy of Sciences

Fandong Zheng

Beijing Water Science and Technology Institute

\section{Research Article}

Keywords: Reclaimed water, Unconfined aquifer, Groundwater table, Groundwater storage, Nitrate loads, Numerical model

Posted Date: November 3rd, 2021

DOI: https://doi.org/10.21203/rs.3.rs-1033197/v1

License: (9) This work is licensed under a Creative Commons Attribution 4.0 International License. Read Full License

Version of Record: A version of this preprint was published at Environmental Science and Pollution Research on January 21st, 2022. See the published version at https://doi.org/10.1007/s11356-02218597-1. 


\section{Abstract}

Reclaimed water (RW) has been widely used as an alternative water resource to recharge rivers in megacity Beijing. At the same time, the RW also recharges the ambient aquifers through riverbank filtration, and modifies the subsurface hydrodynamic system and hydrochemical characteristics. To assess the impact of RW recharge on the unconfined groundwater system, we conducted a 3D groundwater flow and solute transport model based on 10 years of sequenced groundwater monitoring data to analyze the changes of the groundwater table, $\mathrm{Cl}^{-}$loads, and $\mathrm{NO}_{3}-\mathrm{N}$ loads in the shallow aquifer after RW recharge to the river channel. The results show that the groundwater table around the river channel elevated by about 3 4 m quickly after RW recharge from Dec. 2007 to Dec. 2009, and then remained stable due to the continuous RW infiltration. However, the unconfined groundwater storage still declined overall from 2007 to 2014 due to groundwater exploitation. The storage began to recover after groundwater extraction reduction, rising from $3.76 \times 10^{8} \mathrm{~m}^{3}$ at the end of 2014 to $3.85 \times 10^{8} \mathrm{~m}^{3}$ at the end of 2017 . $\mathrm{Cl}^{-}$ concentrations varied from $5 \sim 75 \mathrm{mg} / \mathrm{L}$ before RW recharge to $50 \sim 130 \mathrm{mg} / \mathrm{L}$ in two years (2007-2009), and then remained stable. The zones of the unconfined groundwater quality-affected by RW infiltration increased from $11.7 \mathrm{~km}^{2}$ in 2008 to $26.7 \mathrm{~km}^{2}$ in 2017 . $\mathrm{Cl}^{-}$loads of the unconfined groundwater increased from $1.66 \times 10^{4} \mathrm{t}$ in 2008 to $3.8 \times 10^{3} \mathrm{t}$ in 2017 , while $\mathrm{NO}_{3}-\mathrm{N}$ loads decreased from $29.8 \mathrm{t}$ in 2008 to $11.9 \mathrm{t}$ in 2017 annually in the zones. We determined the maximum area of the unconfined groundwater quality affected by RW, and groundwater outside this area not affected by RW recharge keeps its original state. The RW recharge to the river channel in the study area is beneficial to increase the groundwater table and unconfined groundwater storage with lesser environmental impacts.

\section{Introduction}

The increasing demands for water resources driven by a combination of population growth, socioeconomic development, rapid urbanization, and climate change have been led to water scarcity and quality deterioration (USEPA and USAID, 2012; WWAP, 2019). Facing the ongoing enormous stresses and challenges, reclaimed water (RW) treated from wastewater has been increasingly used as an alternative water resource for different purposes (Asano, 2007; Ahuja, 2015; Deng et al., 2019). RW could be utilized for agricultural irrigation, landscape irrigation, industrial reuse, municipal water, and groundwater recharge (Angelakis and Gikas, 2014; De Gisi et al., 2017; Deng et al., 2019). RW helps increase the reliability of sustainable water supply in many water-scarce areas of the world (Angelakis et al., 2018; Hess and Collins, 2019; Kog, 2020; Tortajada and van Rensburg, 2020; Zhu and Dou, 2018).

In China, RW utilization was $2.17 \times 10^{9}$ in 2009 , accounting for $0.36 \%$ of the total water supply amount (Zhu and Dou, 2018). Then it was up to $8.74 \times 10^{9} \mathrm{~m}^{3}$ in 2019 , accounting for $1.5 \%$ of the total water supply amount (MWR, 2021). Beijing, as a mega-city with serious water shortages, being characterized by drying some rivers with a degraded ecosystem, is the biggest RW user in China (Zhang et al., 2014; MWR, 2021). The amount of Beijing's RW utilization was $6 \times 10^{8}$ in 2008 , accounting for $17 \%$ of the total water supply amount, while it was up to $2 \times 10^{9} \mathrm{~m}^{3}$ in 2020 , accounting for approximately $30 \%$ of the total water 
supply amount (Beijing Water Authority, 2020). Over $90 \%$ of the RW was primarily used for purposes of recreation and ecological conservation (e.g. water supply for recharging rivers or lakes) (Beijing Water Authority, 2019). But compared with other natural water types, RW usually contains higher levels of salts, nitrogen, phosphorus, heavy metals, organic, and biological contaminants, which are controlled by the water treatment technologies (Deng et al., 2019; Valhondo et al., 2020). As a result, groundwater may have potential health risks and environmental impacts as RW seeps into the aquifer by river leakage (Asano and Cotruvo, 2004; Bekele et al., 2018).

It has been demonstrated that some contaminants' concentrations may decrease during the RW infiltration process (e.g., filtration, adsorption, redox reaction, and degradation), such as nutrients (Singer and Brown, 2018), total organic carbon (Bekele et al., 2011), heavy metals (Zhang et al., 2020), trace organic compounds (Li et al., 2015; Ding et al., 2020), and pathogen (Page et al., 2010). RW recharge also changes the interaction of surface water-groundwater and related hydraulic features (Guo et al., 2019; Yuan et al., 2020). Hydrochemical components of groundwater could be modified by the RW mixing with native groundwater along the flow path (Yu et al., 2016; Gilabert-Alarcón et al., 2018; Daesslé et al., 2020). Additionally, the dissolved ions, including arsenic (Fakhreddine et al., 2021) and metals (Davranche and Bollinger, 2000; Patterson et al., 2010) in sediments, can be released into groundwater during the geochemical processes. It brings risks and challenges for water resources management.

The Shunyi reaches of the Chaobai River in Beijing have been dried since 2000, which RW has utilized for recharging river since December 2007 to improve the aquatic ecological conservation of the dry river. Many studies have been carried out on characterizing variations in physical and chemical parameters of groundwater after RW recharge in the study area, with the most significant changes in the unconfined aquifer. The groundwater table increased by $\sim 3 \mathrm{~m}$ after RW supply to the Chaobai River from 2007 to 2018 (He et al., 2021). Column experimental results indicated that cation exchange took place between $\mathrm{K}^{+}$ in the RW and $\mathrm{Ca}^{2+}$ in the riverbed medium during RW infiltration (Liu et al., 2018). The hydrochemical type of the unconfined groundwater has been obviously modified from $\mathrm{HCO}_{3}-\mathrm{Ca} \cdot \mathrm{Mg}$ in 2007 to $\mathrm{HCO}_{3} \cdot \mathrm{Cl}-$ $\mathrm{Na} \cdot \mathrm{Ca} \cdot \mathrm{Mg}$ in 2018 , the latter is similar to the RW type $\left(\mathrm{HCO}_{3} \cdot \mathrm{Cl}-\mathrm{Na} \cdot \mathrm{Ca}\right.$ and $\left.\mathrm{HCO}_{3} \cdot \mathrm{SO}_{4} \cdot \mathrm{Cl}-\mathrm{Na} \cdot \mathrm{Ca}\right)(\mathrm{Li}$ et al., 2019; Jiang et al., 2020; He et al., 2021). It has been observed that salinities of the unconfined groundwater increased, and the total hardness decreased (Liu et al., 2018). Nitrogen (including $\mathrm{NO}_{3}-\mathrm{N}$, $\mathrm{NO}_{2}-\mathrm{N}$, and $\mathrm{NH}_{4}-\mathrm{N}$ ) (Liu et al., 2018; Li et al., 2019) and some endocrine-disrupting chemicals (Li et al., 2013a; Ma et al., 2015; Wang et al., 2019) was observed to be removed during the infiltration process with different removal rates in the column experiments and field monitoring. Nitrogen, especially nitrate, is the typical contaminant in the RW, river, and unconfined groundwater in this area (Yang et al., 2016; Li et al., 2019).

However, few studies have focused on quantifying the effects of RW recharge on the groundwater system. Numerical modeling can be applied to predict groundwater flow and solute transport and evaluate the impacts of human activities (Machiwal et al., 2018; Sege et al., 2018). 
The objectives of this study are to (i) conduct a 3D groundwater flow and solute ( $\mathrm{Cl}^{-}$) transport model, (ii) calculate the changes of unconfined groundwater storage, $\mathrm{Cl}^{-}$loads, and $\mathrm{NO}_{3}-\mathrm{N}$ loads, and (iii) identify the area of groundwater quality affected by the RW recharge and illustrate the environmental impacts in the study area. It can improve understanding of the effects of RW recharge to a river channel on the groundwater system and provide a scientific reference for the safe use of RW and water resources management in other similar regions globally.

\section{Material And Methods \\ 2.1 Study area}

The study area is located in the northeast of Beijing, between longitudes $116^{\circ} 36^{\prime}$ to $116^{\circ} 46^{\prime} \mathrm{E}$ and latitudes $40^{\circ} 02^{\prime}$ to $40^{\circ} 12^{\prime} \mathrm{N}$ (Fig. 1a). Elevation ranges between $22 \mathrm{~m}$ and $54 \mathrm{~m}$.a.s.l (Aji et al., 2008). The area is in the northern temperate region, with a typical continental monsoon climate. The annual average temperature is $\sim 11.5^{\circ} \mathrm{C}$. The mean annual precipitation is about $610 \mathrm{~mm}$, chiefly from June to September. The average annual evaporation based on pan evaporation experiments is about $1108 \mathrm{~mm}$.

The Jian River is an artificial channel with a natural river bottom and sloping brick sides. It is about $4 \mathrm{~km}$ long, 50 90 m wide, and holds approximately $5.1 \cdot 10^{5} \mathrm{~m}^{3}$ of water. The Chaobai River in the study area is a natural channel. It is about $15 \mathrm{~km}$ long, $200 \sim 400 \mathrm{~m}$ wide, and holds approximately $8.91 \cdot 10^{6} \mathrm{~m}^{3}$ of water.

The Chaobai River channel was dry before 2007. Beijing Municipal Water Diversion Project was implemented for restoring the dry river channel by Beijing Water Authority since 2007. The Wenyu River water was pumped and treated by a membrane bioreactor (MBR) to produce RW. Then the RW was transferred into the Jian River and finally flowed into the Chaobai River (Fig. 1a). The transferred volume of RW is $2.9 \cdot 10^{7} \mathrm{~m}^{3}$ in 2017 , and the cumulative transferred volume is $2.3 \cdot 10^{8} \mathrm{~m}^{3}$ from 2007 to 2017 . Dams are set up to control the river water level and separate reaches of the river. RW has replenished the Jian River and Shunyi reach of the Chaobai River since October 2007. The section from the earth dam to the Henan rubber dam (Fig. 1a) is a perennial water-receiving river channel. The section between the Xiangyang sluice and the earth dam is replenished only in May and October as an intermittent waterreceiving river channel. Moreover, the section from the Henan rubber dam to the Suzhuang rubber dam has been perennially replenished since 2012 .

\subsection{Hydrogeology conditions}

The study area locates at the edge of the alluvial fan of the Chaobai River. Stratigraphic distribution can be seen from the hydrogeological profile (Fig. 1b), which is characterized by some interbedded layers. From north to south, sediment grains gradually change from coarse to fine. There are three aquifers of different depths, and each aquifer expresses as the mean depth of the bottom is $30 \mathrm{~m}, 50 \mathrm{~m}$, and $80 \mathrm{~m}$, 
which are mainly composed of gravel and coarse sand (Li et al., 2013b) and separated by clay-rich aquitards. The top $30 \mathrm{~m}$-depth aquifer is unconfined, and $50 \mathrm{~m}$ - depth and $80 \mathrm{~m}$-depth aquifers are confined. The main groundwater pumping layer is the aquifer below 80 m-depth.

The groundwater is mainly recharged by rainfall, river leakage, lateral inflow, and irrigation seepage through the upper aquifer. Groundwater exploitation is the main way of discharge. The average depth of groundwater table in the Xiangyang sluice (G01, G02, and G03) was $29.7 \mathrm{~m}$ in 2017, and the average depth for other monitoring wells in Fig. 1a was $4.4 \mathrm{~m}$ in 2017. The groundwater generally flows from southwest to northeast, which is opposite to the terrain due to the excessive groundwater exploitation (Zheng et al., 2015).

\subsection{Data sources}

Details on input data are summarized in Table 1. All the data were processed into a monthly dataset from December 2007 to December 2017, analyzed for setting up a conceptual model, and finally converted into a numerical model for groundwater flow and solute transport simulation. 
Table 1

Groundwater flow and transport model input data

\begin{tabular}{|c|c|c|}
\hline Input data & Source & Data preparation and main values \\
\hline $\begin{array}{l}\text { Ground } \\
\text { elevation }\end{array}$ & $\begin{array}{l}\text { the Advanced Spaceborne } \\
\text { Thermal Emission and Reflection } \\
\text { Radiometer Global Digital } \\
\text { Elevation Model (resolution of } 1 \\
\text { arc-second) }\end{array}$ & $22 \sim 54 \mathrm{~m}$ \\
\hline $\begin{array}{l}\text { Layers' } \\
\text { thickness }\end{array}$ & $\begin{array}{l}\text { Data from } 14 \text { Boreholes, provided } \\
\text { by Beijing Water Science and } \\
\text { Technology Institute (BWSTI) }\end{array}$ & $\begin{array}{l}\text { The thickness of the seven layers is } 10 \sim 55 \\
\mathrm{~m}, 1 \sim 32 \mathrm{~m}, 1 \sim 29 \mathrm{~m}, 1 \sim 26 \mathrm{~m}, 1 \sim 15 \mathrm{~m}, 1 \sim 19 \\
\mathrm{~m}, \text { and } 104 \sim 150 \mathrm{~m} \text { from top to bottom. }\end{array}$ \\
\hline RW infiltration & $\begin{array}{l}\text { Monthly and annual data of RW } \\
\text { transfer volume are provided by } \\
\text { BWSTI. }\end{array}$ & $\begin{array}{l}\text { Average RW transfer volume: } 2.3 \times 10^{7} \mathrm{~m}^{3} / \mathrm{a} \\
(2008-2017) \text {. The infiltration amount of RW } \\
\text { was calculated by water balance and then } \\
\text { adjusted during the calibration process. }\end{array}$ \\
\hline $\begin{array}{l}\text { Groundwater } \\
\text { withdrawal }\end{array}$ & (Zheng, 2012) & Min: $2.46 \times 10^{6} \mathrm{~m}^{3} / \mathrm{a}$, max: $5.47 \times 10^{7} \mathrm{~m}^{3} / \mathrm{a}$ \\
\hline $\begin{array}{l}\text { Monthly } \\
\text { precipitation }\end{array}$ & $\begin{array}{l}\text { Data from a dataset of monthly } \\
\text { values of climate data from the } \\
\text { Miyun Station in China } \\
\text { meteorological data service } \\
\text { centre }\end{array}$ & $\begin{array}{l}\text { Mean annual precipitation } 633 \text { mm/a (2007- } \\
\text { 2017) }\end{array}$ \\
\hline $\begin{array}{l}\text { Hydrogeological } \\
\text { zones, and } K, S_{S} \\
S_{y}, n, a \text { values }\end{array}$ & (Zheng et al., 2015) & Adjusted during the calibration process \\
\hline $\begin{array}{l}\text { Groundwater } \\
\text { table }\end{array}$ & $\begin{array}{l}14 \text { monitoring wells in the } \\
\text { unconfined aquifer. Data } \\
\text { provided by BWSTI. }\end{array}$ & $\begin{array}{l}\text { All wells are monitored one time per month. } \\
\text { Partially clogged wells are no data in some } \\
\text { months. }\end{array}$ \\
\hline $\begin{array}{l}\mathrm{Cl}^{-} \text {and } \mathrm{NO}_{3}-\mathrm{N} \\
\text { concentration }\end{array}$ & $\begin{array}{l}14 \text { monitoring wells in the } \\
\text { unconfined aquifer. Data } \\
\text { provided by BWSTI. }\end{array}$ & $\begin{array}{l}\text { Each well was sampled from } 3 \text { to } 4 \text { times } \\
\text { per year. }\end{array}$ \\
\hline
\end{tabular}

\subsection{Numerical modeling}

\subsubsection{Groundwater flow and solute transport modeling}

Numerical simulations of groundwater flow and solute transport in this study area were performed using MODFLOW (McDonald and Harbaugh, 1988) and MT3DMS (Zheng et al., 2012) codes, respectively, under the visual MODFLOW software (WHI, 2011). The simulation period was December 2007 to December 2027 with a monthly stress period. The model was conducted with a total simulation time of 241 months, as stress periods. The model domain was discretized into 150 columns and 170 rows with a grid size of $100 \mathrm{~m} \times 100 \mathrm{~m}$. The total thickness of the aquifer system is $200 \mathrm{~m}$ including four aquifers and three aquitards (Fig. 1b). The aquifer system was divided into seven model layers to represent each aquifer and 
aquitard. The top surface elevation was determined using the Digital Elevation Model (DEM). The bottom of each layer was generated by interpolating the boreholes data. Further analysis and discussion in this study focus on the unconfined aquifer (first layer) due to this aquifer has been significantly affected by $\mathrm{RW}$ relative to other aquifers.

According to the monitoring data on the groundwater levels of monitoring wells, the no-flow boundary was applied to the northern boundary $A B$ and the general head boundary applied to the eastern boundary $B C$ and western boundary AD (Fig. S1a). The south boundary CD was characterized by a constant head boundary. The top boundary was the free surface of the unconfined aquifer. The lowest boundary is the bottom of the seventh layer, most of which are limestone and dolomite with low permeability $\left(4.6 \times 10^{-11} \sim 1.2 \times 10^{-9}\right.$ of hydraulic conductivity) (Louis, 1972). This boundary is generalized to the confining boundary.

Water fluxes across the top boundary include recharge from the precipitation infiltration, leakage recharge from the river channel, and discharge through the leakage of the unconfined aquifer and evaporation. Recharge from precipitation is calculated as the product of the monthly values of precipitation in the period 2007-2017 and the local precipitation infiltration coefficient (Fig. S1b) (Zheng, 2012). The river leakage recharge, including the Chaobai River and Jian River, was calculated through water balance in the river channel:

$Q_{R}=Q_{R W}+Q_{P}-Q_{E}-Q_{T}(1)$

where $Q_{R}$ is the river leakage recharge, $Q_{R W}$ is $R W$ transfer volume, $Q_{P}$ is precipitation recharge, $Q_{E}$ is evaporation from the water surface, $Q_{T}$ is the transferred river water to upstream, and the unit is $\mathrm{m}^{3} / \mathrm{a}$.

Due to RW restoring the river channel formed a large surface water area (approximately $5.63 \mathrm{~km}^{2}$ ), river leakage recharge was regarded as planar recharge, the same as precipitation infiltration. The temporal recharge rate in the upper layer can be estimated as a combination of rainfall and river leakage. Groundwater is mainly pumped from the aquifers below $80 \mathrm{~m}$ depth. The well fields were simulated as pumping wells, and their discharge rates were assigned on the fifth and seventh layers. The amount of groundwater evaporation was very small due to the low groundwater table. When the groundwater table depth in the North China Plain is greater than $3 \mathrm{~m}$, evaporation of the unconfined groundwater disappears (Huo, 2015). Thus, the evaporation was simulated in the zones where the groundwater table depth is shallower than $3 \mathrm{~m}$. The observed groundwater levels in the unconfined aquifer and the confined aquifers at the end of 2007 were interpolated as the initial groundwater levels.

The solute transport model was developed based on the groundwater flow model. $\mathrm{Cl}^{-}$as a conservative solute has been generally used to trace and evaluate the impact of RW recharge on subsurface flow systems (Yu et al., 2016; Zhang and $\mathrm{Yu}, 2021$ ). $\mathrm{Cl}^{-}$concentrations of $\mathrm{RW}$ are usually higher than that in natural water. 
The $\mathrm{Cl}^{-}$concentration in the unconfined groundwater increased after RW restoring the river channel. Besides RW, industrial pollution in the study area is also the source of $\mathrm{Cl}^{-}$inputting into groundwater. But the latter didn't affect the unconfined groundwater surrounding the monitoring wells except G32 (He et al., 2021). The high $\mathrm{Cl}^{-}$concentrations in the unconfined groundwater along the river are mainly affected by the RW infiltration. Thus, the river leakage was assumed to be the only source of high concentrations of $\mathrm{Cl}^{-}$in the model. The river was treated as a constant concentration boundary condition with $\mathrm{Cl}^{-}$ concentration of $60 \sim 120 \mathrm{mg} / \mathrm{L}$ according to the observed values. The observed data at the end of 2007 was interpolated to be the initial $\mathrm{Cl}^{-}$concentrations. The $\mathrm{Cl}^{-}$concentrations in rainfall and lateral flow can be set as $2 \mathrm{mg} / \mathrm{L}$ (Gao et al., 2015).

The study area is divided into various parameter zones(Fig. S1C)with different layers. The initial values of hydraulic conductivity $(K)$, storage coefficient $\left(S_{S}\right)$ specific yield $\left(S_{y}\right)$, porosity $(n)$, and dispersion coefficient $(a)$ can be obtained from the previous work done by Zheng et al. (2015) in the study area.

\subsubsection{Model calibration and validation}

The model was calibrated by trial-and-error method based on the groundwater table and the $\mathrm{Cl}^{-}$ concentrations of observation wells from December 2007 to December 2015. The validation period ranges from January 2016 to December 2017. The root means squared error (RMSE) (Eq. 2) and the coefficient of determination ( $\mathrm{R}^{2}$ ) (Eq. 3) were used to evaluate the goodness-of-fit of the calibrated model.

$\operatorname{RMSE}=\sqrt{\frac{1}{\mathrm{n}} \sum_{\mathrm{n}}^{\mathrm{i}=1}\left(\mathrm{O}_{\mathrm{i}}-\mathrm{S}_{\mathrm{i}}\right)^{2}}$

$\mathrm{R}^{2}=\frac{\left(\sum_{\mathrm{n}}^{\mathrm{i}=1}\left(\mathrm{O}_{\mathrm{i}}-\mathrm{O}_{\mathrm{m}}\right)\left(\mathrm{S}_{\mathrm{i}}-\mathrm{S}_{\mathrm{m}}\right)\right)^{2}}{\sum_{\mathrm{n}}^{\mathrm{i}=1}\left(\mathrm{O}_{\mathrm{i}}-\mathrm{O}_{\mathrm{m}}\right)^{2} \sum_{\mathrm{n}}^{\mathrm{i}=1}\left(\mathrm{~S}_{\mathrm{i}}-\mathrm{S}_{\mathrm{m}}\right)^{2}}$

where $n$ is the number of observation points, $O_{i}$ is the ith observed data, $S_{i}$ is the ith simulated result, and $O_{m}$ is the mean value of observed data.

\subsubsection{Scenario design}

Six modeling scenarios were designed based on different conditions to predict groundwater changes and analyze the influences of precipitation, groundwater extraction, and RW recharge (Table 2). A baseline scenario was designed to compare the modeling results of different scenarios. Then, the groundwater dynamics in the next 10 years after 2017 were predicted using the calibrated numerical model. 
Table 2

Scenario design for the groundwater model in the study area

\begin{tabular}{|llll|}
\hline Scenario ID & Precipitation ${ }^{\text {a }}$ & Groundwater extraction ${ }^{\text {b }}$ & RW recharge $^{\text {c }}$ \\
\hline Baseline scenario & $2007-2017$ series & 2017 & Yes \\
\hline 1 & 1993 (dry year) & 2017 & Yes \\
\hline 2 & 2005 (normal year) & 2017 & Yes \\
\hline 3 & 1982 (wet year) & 2017 & Yes \\
\hline 5 & $2007-2017$ series & $25 \%$ reduction & Yes \\
\hline 6 & $2007-2017$ series & $25 \%$ increase & Yes \\
\hline
\end{tabular}

a "2007-2017 series" means the monthly precipitation from 2018 to 2027 repeats the monthly precipitation series from 2007 to 2017. "1993 (dry year)" means the monthly precipitation from 2018 to 2027 repeats the monthly precipitation in1993. And so on, for 2005 (normal year) and 1982 (wet year).

b "2017" means the groundwater extraction volume in all well fields from 2018 to 2027 is the same as the groundwater extraction volume in 2017. "25\% reduction (increase)" means the groundwater extraction volume of the well field A from 2018 to 2027 is decreased (increased) by $25 \%$ compared with 2017.

c "Yes" means RW recharge from 2018 to 2027 remains unchanged, the same as in 2017. "No" means there is no RW recharge from 2018 to 2027.

Climate change affects the hydrological cycle through changes in precipitation and the occurrence of extreme weather. Different annual and seasonal precipitation level changes, the frequency and intensity of floods and droughts, would affect the groundwater system (Schoenheinz and Grischek, 2011).

However, it is difficult to predict the precipitation in the next 10 years based on the existing meteorological data. Therefore, it is necessary to assume multiple data-sets reflecting different precipitation trends for prediction. Based on the monthly precipitation data of the Miyun Station from 1956 to 2020, 1993, 2005, and 1982 were selected to represent the dry, normal, and wet year, respectively. Accordingly, the annual precipitation for the 10 years of model prediction period (2018-2027) was $454.8 \mathrm{~mm}, 574.6 \mathrm{~mm}$, and $710.9 \mathrm{~mm}$, respectively.

Beijing has taken a series of measures to restrict groundwater exploitation (State Council of the People's Republic of China, 2014). The extraction volume of groundwater in the well field $A$ has been halved since 2014. Therefore, two different groundwater exploitation scenarios were set up to discuss the impact of groundwater exploitation on the RW infiltration in the study area. Based on the extraction volume $\left(2.7 \times 10^{7} \mathrm{~m}^{3} / \mathrm{a}\right)$ of the well field $A$ in 2017 , the designed extraction volume of groundwater of the well field A in the next 10 years will increase by $25 \%$ or decrease by $25 \%$ in different scenarios. 
RW infiltration is an important recharge source for groundwater around the river channel. A scenario was set up as no RW recharge in the next 10 years (2018-2027). Compared the difference with or without RW recharge to discuss the impact of RW recharge on surrounding groundwater.

\subsection{Estimation of $\mathrm{Cl}^{-}$and $\mathrm{NO}_{3}-\mathrm{N}$ loads in the unconfined aquifer}

The pollutant load can be calculated from the groundwater storage and pollutant concentration for a given area, reflecting the changes in groundwater pollution under the combined effect of groundwater quantity and quality (Su et al., 2019; Kang et al., 2021). In this study, the concentration gradient was not considered. The formula is as follows:

$P=\sum_{n}^{i=1} C_{i} S_{i}$

where $P$ refers to the $\mathrm{Cl}^{-}$or $\mathrm{NO}_{3}-\mathrm{N}$ loads, $C_{i}$ is the solute concentration of the groundwater in the i cell $(\mathrm{mg} / \mathrm{L})$, and $S_{i}$ is groundwater storage in the i cell $\left(\mathrm{m}^{3}\right)$.

The groundwater table and $\mathrm{Cl}^{-}$concentration of each cell can be obtained from the modeling results. The $\mathrm{NO}_{3}-\mathrm{N}$ concentration of each cell can be gained by interpolating the observed $\mathrm{NO}_{3}-\mathrm{N}$ concentrations in the discrete grids of the model.

\section{Results}

\subsection{Groundwater model calibration and validation}

The RW mainly infiltrates into the unconfined aquifer along the river channel. The average proportion of RW in the unconfined aquifer is the highest of all aquifers from 2007 to 2018, reaching up to 53\% (He et al., 2021). The unconfined aquifer is significantly affected by reclaimed water recharge in groundwater level (Zheng et al., 2015; He et al., 2021), hydrochemistry (Li et al., 2019; Jiang et al., 2020), and water quality (Li et al., 2013a; Ma et al., 2015; Wang et al., 2019). This study focuses on the unconfined aquifer.

The parameters of the first layer of groundwater flow and solute model were calibrated and validated with the history matching. First, the parameters need to be adjusted for minimizing the difference between the observed and simulated outputs. Four typical wells distributed along the bank of recharged river channel from upstream to downstream were selected to represent the groundwater table around the perennial and intermittent water-receiving river channel. Fig. 2 presents the fitted results for the simulated groundwater table and $\mathrm{Cl}^{-}$concentrations in 4 typical observation wells of the unconfined aquifer. During the calibration and validation periods, the RMSE value was $0.35 \mathrm{~m}$, and the $\mathrm{R}^{2}$ value was 0.99 for the groundwater table, and the RMSE value was $11.9 \mathrm{mg} / \mathrm{L}$, and the $\mathrm{R}^{2}$ value was 0.68 for $\mathrm{Cl}^{-}$concentrations, 
respectively. It indicates that the model can be used to predict the variations of the groundwater table and simulate $\mathrm{Cl}^{-}$transport in the aquifer. The zonations of the layers are shown in Fig. S1b. The calibrated parameters of the layers referenced from Zheng et al. (2015) and are shown in Table S1.

\subsection{Changes of the groundwater table and the unconfined groundwater storage}

\subsubsection{Changes in the groundwater table}

Figure 3 shows the simulated results of the groundwater level at the end of 2008, 2009, 2012, and 2017 after RW restoring the river channel. The area with the lowest groundwater table is located in the north of the Xiangyang sluice. The groundwater tables were still falling during the 10 years (2007-2017) after RW recharge, along with groundwater exploitation. The groundwater table in the south of the Xiangyang sluice increased quickly, around $3 \mathrm{~m}$ after the RW recharge for two years (2007-2009). The closer to the river, the more significant the groundwater table rises due to the RW infiltration.

\subsubsection{Groundwater budget analysis}

The groundwater budget of the unconfined aquifer was summarized in Table 3. The total recharge and discharge volume during the simulation period (Dec. 2007-Dec. 2017) was $8.94 \times 10^{8} \mathrm{~m}^{3}$ and $10.23 \times 10^{8}$ $\mathrm{m}^{3}$, respectively, with a reduction in groundwater volume of $1.29 \times 10^{8} \mathrm{~m}^{3}$. The main recharge sources are precipitation infiltration, lateral inflow, and RW infiltration. The amount of precipitation infiltration was $7.56 \times 10^{8} \mathrm{~m}^{3}$ in the simulation period, accounting for $84.6 \%$ of the total recharge. The amount of RW infiltration was $5.9 \times 10^{7} \mathrm{~m}^{3}(6.7 \%)$. For discharge items, the leakage of the unconfined aquifer was $9.97 \times 10^{8} \mathrm{~m}^{3}(97.4 \%)$, which was greater than the total recharge. The groundwater table of the unconfined aquifer was higher than those of the first and second confined aquifers. An increase in the vertical hydraulic gradient due to the deep groundwater pumping enhanced the RW infiltration into the deep aquifers. In contrast, the lateral outflow and evaporation were $2.3 \times 10^{7} \mathrm{~m}^{3}(2.2 \%)$ and $4 \times 10^{6} \mathrm{~m}^{3}(0.4 \%)$. They accounted for a small part of the total discharge volume. Therefore, the discharge leakage of the unconfined aquifer driven by the deep groundwater withdrawal was responsible for the negative balance of the unconfined groundwater storage. 
Table 3

The unconfined groundwater budget from Dec. 2007 to Dec. 2017

\begin{tabular}{|llllll|}
\hline Recharge items & $\begin{array}{l}\text { Volume }\left(\mathbf{1 0}^{8} \mathbf{8}\right. \\
\left.\mathrm{m}^{3}\right)\end{array}$ & $\begin{array}{l}\text { Proportion } \\
\mathrm{a}\end{array}$ & $\begin{array}{l}\text { Discharge } \\
\text { items }\end{array}$ & $\begin{array}{l}\text { Volume }\left(10^{8}\right. \\
\left.\mathrm{m}^{3}\right)\end{array}$ & $\begin{array}{l}\text { Proportion } \\
\mathrm{a}\end{array}$ \\
\hline $\begin{array}{l}\text { Precipitation } \\
\text { infiltration }\end{array}$ & 7.56 & $84.6 \%$ & Leakage & 9.97 & $97.4 \%$ \\
\hline Lateral flow & 0.78 & $8.7 \%$ & Lateral flow & 0.23 & $2.2 \%$ \\
\hline RW infiltration & 0.59 & $6.7 \%$ & Evaporation & 0.04 & $0.4 \%$ \\
\hline Leakage & 0.01 & $0.1 \%$ & & & $100.0 \%$ \\
\hline Total input & 8.94 & & Total output & 10.23 & \\
\hline Storage change & & & -1.29 & & \\
\hline a "Proportion" means the proportion of recharge (discharge) items in total input (output) & \\
\hline
\end{tabular}

\subsection{Variations of the $\mathrm{Cl}^{-}$concentrations}

Figure 4 shows contour maps of the simulated $\mathrm{Cl}^{-}$concentrations at the end of $1 \mathrm{st}, 2 \mathrm{nd}, 5$ th, and 10th years after RW restoring the river channel. The $\mathrm{Cl}^{-}$concentrations in the unconfined groundwater increased from $5 \sim 75 \mathrm{mg} / \mathrm{L}$ to $50 \sim 130 \mathrm{mg} / \mathrm{L}$ from the end of 2007 to 2010 , and then remained stable (Fig. 2d). The groundwater $\mathrm{Cl}^{-}$concentrations in this area decrease with the increasing distance from the river channel. Both precipitation infiltration and subsurface lateral flow played a dilutive effect, the $\mathrm{Cl}^{-}$ concentration in the areas away from the river channel was gradually decreased.

\section{Discussion}

\subsection{Effect of different recharge and discharge conditions on the groundwater system}

The difference of the modeling results in groundwater $\mathrm{Cl}^{-}$concentration under different precipitation scenarios is small than $10 \mathrm{mg} / \mathrm{L}$. The prediction results show that $\mathrm{Cl}^{-}$concentrations in the unconfined groundwater could be rapidly diluted without RW recharge as RW is the only source of high concentrations of $\mathrm{Cl}^{-}$in the model. There is almost no difference in the modeling results in $\mathrm{Cl}^{-}$ concentration under different groundwater extraction scenarios. Therefore, only the influence of different scenarios on the groundwater table will be discussed below.

Precipitation infiltration as the main source of recharge for unconfined groundwater affects the variations of groundwater levels. In different precipitation scenarios, the groundwater table in wet scenario > baseline scenario > normal scenario > dry scenario (Fig. S2). The interannual variation of the groundwater 
table under the baseline scenario is the smallest, approximated as a state of balance. Long-term low rainfall will cause the groundwater table to drop. In Fig. S2d, we can see that the groundwater table in the wet scenario is up to $2 \mathrm{~m}$ and $4 \mathrm{~m}$ higher than in the normal and dry scenarios, respectively, after 10 years.

The scenarios with baseline precipitation and RW recharge (scenarios 4 and 5) demonstrated the impact of groundwater exploitation. Fig. S3 shows the groundwater table under different groundwater extraction scenarios. The results show that the reduction in groundwater withdrawal can recover the groundwater table. The closer to the well field, the greater the groundwater table changes affected by groundwater extraction. For example, the well G01 closest to the well field has a maximum groundwater table amplitude of $\sim 2 \mathrm{~m}$ between the increase and reduction scenarios (Fig. S3a).

The scenario of baseline precipitation and groundwater extraction (scenario 6) was designed to demonstrate the influence of RW recharge. Compared with the baseline scenario, the groundwater table dropped when there was no RW recharge and then reached a relatively stable state. The difference in groundwater table with and without RW recharge is about $3 \mathrm{~m}, 5 \mathrm{~m}, 11 \mathrm{~m}$, and $5 \mathrm{~m}$ at G01, G15, G22, and G30, respectively (Fig. S4). It indicates that the continuous RW recharge helps maintain the groundwater table stable. When there is no RW recharge, the groundwater table around the river channel will reduce to a low level.

\subsection{Variations of the unconfined groundwater storage}

The unconfined groundwater storage can be calculated by the simulated groundwater table each year at the end of December (Fig. 5). The storage decreased year by year from $4.83 \times 10^{8} \mathrm{~m}^{3}$ at the end of 2007 to $3.88 \times 10^{8} \mathrm{~m}^{3}$ at the end of 2011 . Although the groundwater table around the river has risen after the RW recharged, the groundwater table in the north Xiangyang sluice has been falling due to the continuous groundwater exploitation. Since 2012, the section between Henan rubber dam and Suzhuang rubber dam has been replenished by the RW. The storage increased to $4.1 \times 10^{8} \mathrm{~m}^{3}$ by the end of 2012 , then continued to decline and was up to $3.76 \times 10^{8} \mathrm{~m}^{3}$ at the end of 2014 (Fig. 5).

In December 2014, the South-to-North Water Diversion Project began to transfer water to Beijing. The amount of groundwater extraction in the well field, which is located in the north of the Xiangyang sluice, has been halved. The declining trend of the confined groundwater level has slowed down. Moreover, the annual average leakage of the unconfined aquifer has decreased from $1.04 \times 10^{8} \mathrm{~m}^{3} / \mathrm{a}(2008-2013)$ to $8.81 \times 10^{7} \mathrm{~m}^{3} / \mathrm{a}(2014-2017)$. Due to the continuous RW infiltration and the groundwater extraction reduction, storage began to rise slowly since 2014 . It rose from $3.76 \times 10^{8} \mathrm{~m}^{3}$ at the end of 2014 to $3.85 \times 10^{8} \mathrm{~m}^{3}$ at the end of 2017 (Fig. 5). 


\subsection{Distribution of the unconfined groundwater-affected by the RW infiltration}

The increase of $\mathrm{Cl}^{-}$concentrations may reflect the impact of RW infiltration on groundwater. The zones where the $\mathrm{Cl}^{-}$concentration is higher than the initial concentration $(5 \sim 75 \mathrm{mg} / \mathrm{L})$ after $\mathrm{RW}$ recharge is defined as being affected by RW infiltration. Fig. 6 shows zones of the unconfined groundwater quality affected by RW for the 1st, 2nd, 5th, and 10th years after RW restoring the river channel. The $\mathrm{Cl}^{-}$transport is controlled by both the groundwater flow rate and the concentration gradient. In the early stage of reclaimed water replenishment, the groundwater table elevated rapidly due to the RW infiltration, resulting in quick $\mathrm{Cl}^{-}$movement with the groundwater flow. Thus, the zones affected by RW are distributed at both sides of the river. Due to the unconfined groundwater flows from southwest to northeast, the affected zone of the left bank is more extensive than that at the right bank (Fig. 6). The affected zones gradually expanded with the increase of time and recharged channels, but the annual increasing rate of the area decreased year by year (Table 4). It indicates that $\mathrm{Cl}^{-}$movement slowed down with the groundwater table stable around the river.

Table 4

Variations of the zones affected by RW infiltration for the unconfined groundwater

\begin{tabular}{|lcccccccccc|}
\hline Year & $\mathbf{2 0 0 8}$ & $\mathbf{2 0 0 9}$ & $\mathbf{2 0 1 0}$ & $\mathbf{2 0 1 1}$ & $\mathbf{2 0 1 2}$ & $\mathbf{2 0 1 3}$ & $\mathbf{2 0 1 4}$ & $\mathbf{2 0 1 5}$ & $\mathbf{2 0 1 6}$ & $\mathbf{2 0 1 7}$ \\
\hline Area $\left(\mathrm{km}^{2}\right)$ & 11.7 & 14.9 & 16.4 & 17.8 & 22.2 & 23.3 & 24.6 & 25.7 & 26.4 & 26.7 \\
$\begin{array}{l}\text { Increasing } \\
\text { rate }(\%)\end{array}$ & 27.4 & 9.8 & 8.8 & 24.5 & 5.3 & 5.3 & 4.6 & 2.5 & 1.4 \\
\hline
\end{tabular}

\subsection{Variations of the $\mathrm{Cl}^{-}$and $\mathrm{NO}_{3}-\mathrm{N}$ loads}

\subsection{1 $\mathrm{Cl}^{-}$loads in the unconfined groundwater}

The $\mathrm{Cl}^{-}$loads in the model area were decreased annually, dropped from $1.66 \times 10^{4} \mathrm{t}$ at the end of 2007 to $3.85 \times 10^{3} \mathrm{t}$ at the end of 2017 (Fig. 5). In contrast, the $\mathrm{Cl}^{-}$loads in the affected zones rose from $1.8 \times 10^{3} \mathrm{t}$ at the end of 2008 to $3.8 \times 10^{3} \mathrm{t}$ at the end of 2017 . There are rising trends both in the $\mathrm{Cl}^{-}$concentrations, and $\mathrm{Cl}^{-}$loads of the unconfined groundwater in the affected zones. The zone can represent where the unconfined groundwater quality is affected by RW in terms of solute concentration and corresponding loads.

\subsection{2 $\mathrm{NO}_{3}-\mathrm{N}$ loads in the affected zones}


$\mathrm{NO}_{3}-\mathrm{N}$ is the typical contaminant in the RW (Pan et al., 2018; Li et al., 2019). Although $\mathrm{NO}_{3}-\mathrm{N}$ has been partially removed during the RW infiltration process, $\mathrm{NO}_{3}-\mathrm{N}$ from the $\mathrm{RW}$ still enters the groundwater ( $\mathrm{Li}$ et al., 2019). The observed $\mathrm{NO}_{3}-\mathrm{N}$ concentrations of some monitoring wells occasionally exceed $10 \mathrm{mg} / \mathrm{L}$ (guideline for drinking water recommended by WHO (World Health Organization, 2017)). Furthermore, the change trends of groundwater $\mathrm{NO}_{3}-\mathrm{N}$ concentrations during monitoring periods were consistent with those of groundwater $\mathrm{Cl}^{-}$concentrations, being affected by seasonal precipitation and temperature changes (Li, 2020).

Figure 5 shows the calculated groundwater $\mathrm{NO}_{3}-\mathrm{N}$ loads within the affected zones at the end of each year, declining from $29.8 \mathrm{t}$ at the end of 2008 to $11.9 \mathrm{t}$ at the end of 2017. It indicates that the RW infiltration did not increase the $\mathrm{NO}_{3}-\mathrm{N}$ loads in the unconfined groundwater.

Although the maximum $\mathrm{NO}_{3}-\mathrm{N}$ concentration in the $\mathrm{RW}$ is as high as $20.2 \mathrm{mg} / \mathrm{L}$, the unconfined groundwater has been subjected to denitrification during the RW infiltration, especially in the south of the Xiangyang sluice (Liu et al., 2018). Denitrification hotspots are easily formed during surface water infiltration (Rivett et al., 2008; Ranalli and Macalady, 2010; Trauth et al., 2018). The attenuation rate of $\mathrm{NO}_{3}-\mathrm{N}$ near the monitoring well G22 can reach $99.6 \%$ (Li et al., 2019).

There was a high level $(48.8 \mathrm{t})$ of $\mathrm{NO}_{3}-\mathrm{N}$ loads at the end of 2011. The $\mathrm{NO}_{3}-\mathrm{N}$ contents near the Xiangyang sluice are relatively high due to the existing thick gravel layer, which is not conducive to remove $\mathrm{NO}_{3}-\mathrm{N}$ (Xiong, 2009). The north channel of the earth dam has been replenished only in May and October. Sediments can adsorb $\mathrm{NH}_{4}-\mathrm{N}$ during the wet period, which can be converted by nitrification reaction into $\mathrm{NO}_{3}-\mathrm{N}$ during the dry period (Böhlke et al., 2006). Therefore, the unconfined groundwater near the intermittent water-receiving channel appeared high $\mathrm{NO}_{3}-\mathrm{N}$ concentrations $(\sim 14.7 \mathrm{mg} / \mathrm{L})$.

\subsection{Environmental implications for management of a river channel recharged by RW}

RW has been used to restore the Chaobai River, while the unconfined aquifer near the river channel was unintentionally recharged. It can be considered as a riverbank filtration (RBF) system, a way of anthropogenic aquifer recharge (AAR) (Todd, 1959; Morel-Seytoux, 1985; Dillon, 2005; NRMMC et al., 2009; Maliva, 2020a). As a result, the RW infiltration affects the groundwater level and quality around the river channel, especially the unconfined groundwater.

The RW infiltration has quickly replenished the unconfined groundwater, resulting in the groundwater table around the river channel to rose rapidly by 3 4 $\mathrm{m}$ in the first two years (2007-2009) (Zheng et al., 2015; He et al., 2021). However, increased recharge via the RW infiltration may not necessarily result in a corresponding increase in the groundwater storage volume (Maliva, 2020b). According to the calculated results of the unconfined groundwater storage in this study, it is necessary to combine the increase RW 
recharge and reduction extractions to sustain the groundwater storage. Increasing recharge in isolation may not solve the problem of groundwater over-extraction (Gale et al., 2006; Foster and Garduño, 2013).

Water quality issues are usually the most concern in the RW utilization. The infiltration process driven by natural filtration and groundwater pumping improves or degrades the recharged water quality. It depends on the quantity and hydrochemical characteristics of RW and native groundwater, and the geochemical processes occurring during RW passes via riverbed and underlying aquifer (Ray, 2008; Stuyfzand, 2011; Tyagi et al., 2013; Hu et al., 2016). In the study area, the subsurface hydrochemistry might be modified by mixing the infiltrated RW with native groundwater and potential water-rock interactions, especially the mixing process and cation exchange (Yu, 2013; Liu et al., 2018). The hydrochemical type of the unconfined groundwater has changed from $\mathrm{HCO}_{3}-\mathrm{Ca} \cdot \mathrm{Mg}$ into $\mathrm{HCO}_{3} \cdot \mathrm{Cl}-\mathrm{Na} \cdot \mathrm{Ca}$, which is the RW type (Li et al., 2019; Jiang et al., 2020). The hydraulic travel time of RW infiltration into the $30 \mathrm{~m}$ depth was about 6.5 months (Li et al., 2019). The average proportion of the RW in the unconfined aquifers is about $53 \%$ from 2007 to 2018 (He et al., 2021). $\mathrm{NO}_{3}-\mathrm{N}$ in the RW was well attenuated with an attenuation rate of $99.6 \%$ during infiltration ( $\mathrm{Li}$ et al., 2019). Some emerging contaminants have been detected in the unconfined groundwater from this area, such as endocrine-disrupting compounds (Li et al., 2013a; Ma et al., 2015) and antibiotics and antibiotic resistance genes (Zhang et al., 2018).

Although the RW recharge to a river channel may inevitably affect the groundwater quality of the underlying aquifers, the affected zones are limited. In the affected zones, the $\mathrm{Cl}^{-}$loads of the unconfined groundwater were increased and $\mathrm{NO}_{3}-\mathrm{N}$ loads of the unconfined groundwater attenuated in the zones. But outside of these affected zones, the groundwater quality is characterized by the initial concentration of the aquifer.

RW utilization for recharging the river channel and the ambient groundwater system is usually a doubleedged sword, which can bring the environment both benefits and harms. The main benefits are restoring the riverine ecosystem, increasing and maintaining the groundwater table and storage, and reducing groundwater pumping. At the same time, the disadvantage lies in the potential deterioration of groundwater quality, which depends on the inputs. attenuation of contaminants, and potential water-rock interaction in river-aquifer systems. Where conditions are hydro-geologically favorable, RW recharge to the river channel can be a valuable way of alleviating water shortages (Maliva, 2020a). It is important and necessary to investigate and evaluate whether the field is suitable for RW recharge (Alam et al., 2021). Based on the numerical modeling, this study shows that apart from the affected zones, the RW has lesser environmental impacts of RW infiltration on groundwater quality. In future work, we should pay more attention to variations of water quality after RW recharge, and take necessary measures to manage RW recharge. It is an essential aspect of ensuring the safe use of RW. Additionally, as the unconfined groundwater table rise, a threshold of water level should be set to prevent soil salinization in the RW receiving area.

\section{Conclusions}


Since the operation of the Beijing Municipal Water Diversion Project in 2007, it has been more than ten years since the implementation of reclaimed water supply to the Chaobai River, resulting in some environmental effects (e.g. groundwater level rise and water quality change). Based on long timesequenced groundwater monitoring data, this study established a three-dimensional groundwater flow and solute transport model to evaluate the impact of the RW recharge on the groundwater table and storage change, and $\mathrm{Cl}^{-}$and $\mathrm{NO}_{3}-\mathrm{N}$ loads in the unconfined aquifer. Seven scenarios are designed to reveal the influence of different precipitation, groundwater extraction, and RW recharge conditions on the unconfined groundwater system.

The results show that the groundwater table around the river channel rose by about $3 \sim 4 \mathrm{~m}$ from Dec. 2007 to Dec. 2009 after RW recharge and then remained stable. The groundwater exploitation caused the declining groundwater table near the well field in the north of the Xiangyang sluice, and the unconfined groundwater was in a negative equilibrium state from Dec. 2007 to Dec. 2017. The continuous recharge of RW and the reduced groundwater exploitation increased the unconfined groundwater storage. Reducing the amount of groundwater exploitation by $25 \%$ can increase the surrounding groundwater table by $\sim 1 \mathrm{~m}$ in 10 years (2018-2027). Stop supplying reclaimed water, and the unconfined groundwater table around the river channel will drop by $\sim 5 \mathrm{~m}$ in 10 years (2018-2027).

The range of $\mathrm{Cl}^{-}$concentrations in the unconfined groundwater significantly increased from $5 \sim 75 \mathrm{mg} / \mathrm{L}$ before RW recharge to $50 \sim 130 \mathrm{mg} / \mathrm{L}$ due to the RW infiltration. The affected zones can be identified by the increase of $\mathrm{Cl}^{-}$concentration. The RW-affected area increased from $11.7 \mathrm{~km}^{2}$ in 2008 to $26.7 \mathrm{~km}^{2}$ in 2017. The affected zones tend to be annually stable with a steady $\mathrm{RW}$ supply. The $\mathrm{Cl}^{-}$loads of the unconfined groundwater in the affected zones were increased annually, but the $\mathrm{NO}_{3}-\mathrm{N}$ loads were decreasing as a whole due to $\mathrm{NO}_{3}-\mathrm{N}$ attenuated in the zones.

In general, the river channel recharged by RW in the study area is beneficial to increase and maintain the groundwater table and the groundwater storage with lesser environmental impacts. To a large extent, the pressure on water demand in Beijing has been relieved. It suggests that long-term monitoring of surface and groundwater quality around the river channel can be implemented to keep a watchful eye on changes in groundwater quality and environmental impacts. Improving the RW quality and optimizing replenishment plans through modeling are recommended for water management around the river channel recharged by RW. In order to minimize the negative environmental effects, it is necessary to regulate the water quality and quantity in the long run to realize the optimal utilization of reclaimed water.

\section{Declarations}

\section{Ethics approval and consent to participate}

Not applicable. 


\section{Consent for publication}

Not applicable.

\section{Availability of data and materials}

The datasets used and analysed during the current study are available from the corresponding author on reasonable request.

\section{Competing interests}

The authors declare that they have no competing interests.

\section{Funding}

This research was funded by the Beijing Municipal Natural Science Foundation (Grant No. 8212035) and the National Natural Science Foundation of China (Grant No. 41730749).

\section{Authors' contributions}

Conceptualization: Ruixue Jiang, Dongmei Han, Xianfang Song and Fandong Zheng; Formal analysis, Software, and Visualization: Ruixue Jiang, Dongmei Han; Investigation: Ruixue Jiang, Dongmei Han and Fandong Zheng; Funding acquisition: Xianfang Song, Dongmei Han; Resources: Xianfang Song, Dongmei Han and Fandong Zheng; Supervision: Dongmei Han, Xianfang Song; Writing - original draft preparation: Ruixue Jiang, Dongmei Han; Writing - review and editing: Ruixue Jiang, Dongmei Han and Xianfang Song.

\section{Acknowledgements}

We are grateful for Dr. Zhao Zhanfeng's help in setting up the model.

\section{References}

1. Ahuja S (2015) Overview of Global Water Challenges and Solutions, in: Water Challenges and Solutions on a Global Scale, ACS Symposium Series. American Chemical Society, pp. 1-25. https://doi.org/10.1021/bk-2015-1206.ch001

2. Aji K, Tang C, Song X, Kondoh A, Sakura Y, Yu J, Kaneko S (2008) Characteristics of chemistry and stable isotopes in groundwater of Chaobai and Yongding River basin, North China Plain. Hydrol Process 22:63-72. https://doi.org/10.1002/hyp.6640 
3. Alam S, Borthakur A, Ravi S, Gebremichael M, Mohanty SK (2021) Managed aquifer recharge implementation criteria to achieve water sustainability. Science of The Total Environment 768:144992. https://doi.org/10.1016/j.scitotenv.2021.144992

4. Angelakis AN, Asano T, Bahri A, Jimenez BE, Tchobanoglous G (2018) Water Reuse: From Ancient to Modern Times and the Future. Front Environ Sci 6:26. https://doi.org/10.3389/fenvs.2018.00026

5. Angelakis AN, Gikas P (2014) Water reuse: Overview of current practices and trends in the world with emphasis on EU states. Water Utility Journal 8:67-78

6. Asano T (2007) Water reuse: issues, technologies, and applications. McGraw-Hill, New York

7. Asano T, Cotruvo JA (2004) Groundwater recharge with reclaimed municipal wastewater: health and regulatory considerations. Water Res 38:1941-1951. https://doi.org/10.1016/j.watres.2004.01.023

8. Beijing Water A (2020) Beijing Water Resources Bulletin (2019). Beijing Water Authority, Beijing

9. Beijing Water A (2019) Beijing Water Statistical Yearbook (2018). Beijing Water Authority

10. Bekele E, Page D, Vanderzalm J, Kaksonen A, Gonzalez D (2018) Water Recycling via Aquifers for Sustainable Urban Water Quality Management: Current Status, Challenges and Opportunities. Water 10:457. https://doi.org/10.3390/w10040457

11. Bekele E, Toze S, Patterson B, Higginson S (2011) Managed aquifer recharge of treated wastewater: Water quality changes resulting from infiltration through the vadose zone. Water Res 45:5764-5772. https://doi.org/10.1016/j.watres.2011.08.058

12. Böhlke JK, Smith RL, Miller DN (2006) Ammonium transport and reaction in contaminated groundwater: Application of isotope tracers and isotope fractionation studies. Water Resour Res 42. https://doi.org/10.1029/2005WR004349

13. Daesslé LW, Andrade-Tafoya PD, Lafarga-Moreno J, Mahlknecht J, van Geldern R, Beramendi-Orosco LE, Barth JAC (2020) Groundwater recharge sites and pollution sources in the wine-producing Guadalupe Valley (Mexico): Restrictions and mixing prior to transfer of reclaimed water from the USMéxico border. Science of The Total Environment 713:136715. https://doi.org/10.1016/j.scitotenv.2020.136715

14. Davranche M, Bollinger J-C (2000) Heavy Metals Desorption from Synthesized and Natural Iron and Manganese Oxyhydroxides: Effect of Reductive Conditions. J Colloid Interface Sci 227:531-539. https://doi.org/10.1006/jcis.2000.6904

15. De Gisi S, Casella P, Cellamare CM, Ferraris M, Petta L, Notarnicola M (2017) Wastewater Reuse. In: Abraham MA (ed) Encyclopedia of Sustainable Technologies. Elsevier, Oxford, pp 53-68. https://doi.org/10.1016/B978-0-12-409548-9.10528-7

16. Deng S, Yan X, Zhu Q, Liao C (2019) The utilization of reclaimed water: Possible risks arising from waterborne contaminants. Environ Pollut 254:113020. https://doi.org/10.1016/j.envpol.2019.113020

17. Dillon P (2005) Future management of aquifer recharge. Hydrogeol J 13:313-316. https://doi.org/10.1007/s10040-004-0413-6 
18. Ding G, Chen G, Liu Y, Li M, Liu X (2020) Occurrence and risk assessment of fluoroquinolone antibiotics in reclaimed water and receiving groundwater with different replenishment pathways. Science of The Total Environment 738:139802. https://doi.org/10.1016/j.scitotenv.2020.139802

19. Fakhreddine S, Prommer H, Scanlon BR, Ying SC, Nicot J-P (2021) Mobilization of Arsenic and Other Naturally Occurring Contaminants during Managed Aquifer Recharge: A Critical Review. Environ Sci Technol. https://doi.org/10.1021/acs.est.0c07492

20. Foster S, Garduño H (2013) Irrigated agriculture and groundwater resources - towards an integrated vision and sustainable relationship. Water Sci Technol 67:1165-1172. https://doi.org/10.2166/wst.2013.654

21. Gale IN, Macdonald DMJ, Calow RC, Neumann I, Moench M, Kulkarni H, Mudrakartha S, Palanisami K (2006) Managed aquifer recharge: An assessment of its role and effectiveness in watershed management. British Geological Survey, Nottingham

22. Gao X, Chen X, Ding Z, Yang W (2015) Investigation of the variation of atmospheric pollutants from chemical composition of precipitation along an urban-to-rural transect in Beijing. Acta Sci Circum 35:4033-4042

23. Gilabert-Alarcón C, Daesslé LW, Salgado-Méndez SO, Pérez-Flores MA, Knöller K, Kretzschmar TG, Stumpp C (2018) Effects of reclaimed water discharge in the Maneadero coastal aquifer, Baja California, Mexico. Appl Geochem 92:121-139. https://doi.org/10.1016/j.apgeochem.2018.03.006

24. Guo X, Feng Q, Si J, Xi H, Zhao Y, Deo RC (2019) Partitioning groundwater recharge sources in multiple aquifers system within a desert oasis environment: Implications for water resources management in endorheic basins. J Hydrol 579:124212. https://doi.org/10.1016/j.jhydrol.2019.124212

25. He Z, Han D, Song X, Yang L, Zhang Y, Ma Y, Bu H, Li B, Yang S (2021) Variations of Groundwater Dynamics in Alluvial Aquifers with Reclaimed Water Restoring the Overlying River, Beijing, China. Water 13:806. https://doi.org/10.3390/w13060806

26. Hess DJ, Collins BM (2019) Recycling water in US cities: understanding preferences for aquifer recharging and dual-reticulation systems. Water Policy 21:1207-1223. https://doi.org/10.2166/wp.2019.162

27. Hu B, Teng Y, Zhai Y, Zuo R, Li J, Chen H (2016) Riverbank filtration in China: A review and perspective. J Hydrol 541:914-927. https://doi.org/10.1016/j.jhydrol.2016.08.004

28. Huo S (2015) Research on the Effect of Water Table Decline on Vertical Groundwater Recharge--A Case Study in the North China Plain (Doctor). China University of Geosciences

29. Jiang R, Han D, Song X, Yang L, Li B (2020) Impacts of reclaimed water recharge to river channel on ambient water bodies: a case study of Beijing Chaobai River. Resources Science 42:2419-2433. https://doi.org/10.18402/resci.2020.12.13

30. Kang J-H, Park M-H, Ha SJ, Stenstrom MK (2021) An empirical modeling approach to predicting pollutant loads and developing cost-effective stormwater treatment strategies for a large urban 
watershed. Science of The Total Environment 760:143388.

https://doi.org/10.1016/j.scitotenv.2020.143388

31. Kog YC (2020) Water Reclamation and Reuse in Singapore. J Environ Eng-ASCE 146:03120001. https://doi.org/10.1061/(ASCE)EE.1943-7870.0001675

32. Li C (2020) Analysis of Evolution Characteristics of Groundwater Quality under River Infiltration Recharge with Reclaimed Water (Master). China University of Geosciences (Beijing), Beijing

33. Li C, Li B, Bi E (2019) Characteristics of hydrochemistry and nitrogen behavior under long-term managed aquifer recharge with reclaimed water: A case study in north China. Science of The Total Environment 668:1030-1037. https://doi.org/10.1016/j.scitotenv.2019.02.375

34. Li J, Fu J, Zhang H, Li Z, Ma Y, Wu M, Liu X (2013a) Spatial and seasonal variations of occurrences and concentrations of endocrine disrupting chemicals in unconfined and confined aquifers recharged by reclaimed water: A field study along the Chaobai River, Beijing. Science of The Total Environment 450-451:162-168. https://doi.org/10.1016/j.scitotenv.2013.01.089

35. Li J, Fu J, Zhang H, Li Z, Ma Y, Wu M, Liu X (2013b) Spatial and seasonal variations of occurrences and concentrations of endocrine disrupting chemicals in unconfined and confined aquifers recharged by reclaimed water: A field study along the Chaobai River, Beijing. Science of The Total Environment 450-451:162-168. https://doi.org/10.1016/j.scitotenv.2013.01.089

36. Li Z, Xiang X, Li M, Ma Y, Wang J, Liu X (2015) Occurrence and risk assessment of pharmaceuticals and personal care products and endocrine disrupting chemicals in reclaimed water and receiving groundwater in China. Ecotoxicol Environ Saf 119:74-80.

https://doi.org/10.1016/j.ecoenv.2015.04.031

37. Liu L, Shan Y, Li B, Yang Y (2018) Interaction mechanism experiment of water and rocks in infiltration of reclaimed water. Water Resources Protection 34:31-35

38. Louis C (1972) Rock Hydraulics. Rock Mechanics 299-387. https://doi.org/10.1007/978-3-70914109-0_16

39. Ma W, Nie C, Su F, Cheng X, Yan Y, Chen B, Lun X (2015) Migration and biotransformation of three selected endocrine disrupting chemicals in different river-based aquifers media recharge with reclaimed water. International Biodeterioration \& Biodegradation, CESE-2014 - Challenges in Environmental Science and Engineering Series Conference 102, 298-307. https://doi.org/10.1016/j.ibiod.2015.03.022

40. Machiwal D, Jha MK, Singh VP, Mohan C (2018) Assessment and mapping of groundwater vulnerability to pollution: Current status and challenges. Earth Sci Rev 185:901-927. https://doi.org/10.1016/j.earscirev.2018.08.009

41. Maliva RG (2020a) Introduction to Anthropogenic Aquifer Recharge. In: Maliva RG (ed) Anthropogenic Aquifer Recharge: WSP Methods in Water Resources Evaluation Series No. 5, Springer Hydrogeology. Springer International Publishing, Cham, pp 1-20. https://doi.org/10.1007/978-3-03011084-0_1 
42. Maliva RG (2020b) Groundwater Recharge and Aquifer Water Budgets. In: Maliva RG (ed) Anthropogenic Aquifer Recharge: WSP Methods in Water Resources Evaluation Series No. 5, Springer Hydrogeology. Springer International Publishing, Cham, pp 63-102. https://doi.org/10.1007/978-3030-11084-0_4

43. McDonald MG, Harbaugh AW (1988) A Modular Three-dimensional Finite-difference Ground-water Flow Model. U.S. Geological Survey

44. Morel-Seytoux HJ (1985) CHAPTER 3 - Conjunctive Use of Surface and Ground Waters, in: Asano, T. (Ed.), Artificial Recharge of Groundwater. Butterworth-Heinemann, pp. 35-67. https://doi.org/10.1016/B978-0-250-40549-7.50008-4

45. MWR (2021) China Water Resources Bulletin (2019). Ministry of Water Resources of the People's Republic of China

46. NRMMC EPHC, NHMRC, 2009. Water Quality Australian guidelines for water recycling: Managed Aquifer Recharge. https://www.waterquality.gov.au/guidelines/recycled-water\#managing-health-andenvironmental-risks-phase-1 (accessed 1 December 2019)

47. Page D, Dillon P, Toze S, Bixio D, Genthe B, Jiménez Cisneros BE, Wintgens T (2010) Valuing the subsurface pathogen treatment barrier in water recycling via aquifers for drinking supplies. Water Res 44:1841-1852. https://doi.org/10.1016/j.watres.2009.12.008

48. Pan W, Huang Q, Huang G (2018) Nitrogen and Organics Removal during Riverbank Filtration along a Reclaimed Water Restored River in Beijing, China. Water 10:491. https://doi.org/10.3390/w10040491

49. Patterson BM, Shackleton M, Furness AJ, Pearce J, Descourvieres C, Linge KL, Busetti F, Spadek T (2010) Fate of nine recycled water trace organic contaminants and metal(loid)s during managed aquifer recharge into a anaerobic aquifer: Column studies. Water Res 44:1471-1481. https://doi.org/10.1016/j.watres.2009.10.044

50. Ranalli AJ, Macalady DL (2010) The importance of the riparian zone and in-stream processes in nitrate attenuation in undisturbed and agricultural watersheds - A review of the scientific literature. J Hydrol 389:406-415. https://doi.org/10.1016/j.jhydrol.2010.05.045

51. Ray C (2008) Worldwide potential of riverbank filtration. Clean Techn Environ Policy 10:223-225. https://doi.org/10.1007/s10098-008-0164-5

52. Rivett MO, Buss SR, Morgan P, Smith JWN, Bemment CD (2008) Nitrate attenuation in groundwater: A review of biogeochemical controlling processes. Water Res 42:4215-4232.

https://doi.org/10.1016/j.watres.2008.07.020

53. Schoenheinz D, Grischek T (2011) Behavior of Dissolved Organic Carbon During Bank Filtration Under Extreme Climate Conditions. In: Shamrukh M (ed) Riverbank Filtration for Water Security in Desert Countries, NATO Science for Peace and Security Series C: Environmental Security. Springer Netherlands, Dordrecht, pp 51-67. https://doi.org/10.1007/978-94-007-0026-0_4

54. Sege J, Ghanem M, Ahmad W, Bader H, Rubin Y (2018) Distributed data collection and web-based integration for more efficient and informative groundwater pollution risk assessment. Environ Model Softw 100, 278-290. https://doi.org/10.1016/j.envsoft.2017.11.027 
55. Singer R, Brown S (2018) Impact of Soil Filtration on Metals, Nutrients, and Estrogenic Activity of Reclaimed Water. J Environ Qual 47:1504-1512. https://doi.org/10.2134/jeq2018.03.0109

56. State Council of the People's Republic of China (2014) Regulations on Water Supply Management of the South-to-North Water Diversion Project

57. Stuyfzand PJ (2011) Hydrogeochemical Processes During Riverbank Filtration and Artificial Recharge of Polluted Surface Waters: Zonation, Identification, and Quantification. In: Shamrukh M (ed) Riverbank Filtration for Water Security in Desert Countries. NATO Science for Peace and Security Series C: Environmental Security. Springer Netherlands, Dordrecht, pp 97-128. https://doi.org/10.1007/978-94-007-0026-0_7

58. Su Y, Li K, Liang S, Lu S, Wang Y, Dai A, Li Y, Ding D, Wang X (2019) Improved simulationoptimization approach for identifying critical and developable pollution source regions and critical migration processes for pollutant load allocation. Science of The Total Environment 646:13361348. https://doi.org/10.1016/j.scitotenv.2018.07.326

59. Todd DK (1959) Annotated bibliography on artificial recharge of ground water through 1954 (No. 1477), Water Supply Paper. U.S. Govt. Print. Off.,. https://doi.org/10.3133/wsp1477

60. Tortajada C, van Rensburg P (2020) Drink more recycled wastewater. Nature 577:26-28. https://doi.org/10.1038/d41586-019-03913-6

61. Trauth N, Musolff A, Knöller K, Kaden US, Keller T, Werban U, Fleckenstein JH (2018) River water infiltration enhances denitrification efficiency in riparian groundwater. Water Res 130:185-199. https://doi.org/10.1016/j.watres.2017.11.058

62. Tyagi S, Dobhal R, Kimothi PC, Adlakha LK, Singh P, Uniyal DP (2013) Studies of River Water Quality Using River Bank Filtration in Uttarakhand, India. Water Qual Expo Health 5:139-148. https://doi.org/10.1007/s12403-013-0097-z

63. USEPA USAID (2012) Guidelines for Water Reuse (No. EPA/600/R-12/618). U.S. Environmental Protection Agency, Washington, D.C.

64. Valhondo C, Carrera J, Martínez-Landa L, Wang J, Amalfitano S, Levantesi C, Diaz-Cruz MS (2020) Reactive Barriers for Renaturalization of Reclaimed Water during Soil Aquifer Treatment. Water 12:1012. https://doi.org/10.3390/w12041012

65. Wang P, Rene ER, Yan Y, Ma W, Xiang Y (2019) Spatiotemporal evolvement and factors influencing natural and synthetic EDCs and the microbial community at different groundwater depths in the Chaobai watershed: A long-term field study on a river receiving reclaimed water. J Environ Manage 246:647-657. https://doi.org/10.1016/j.jenvman.2019.05.156

66. World Health Organization (2017) Guidelines for drinking-water quality: fourth edition incorporating the first addendum. Geneva

67. WWAP (2019) The United Nations World Water Development Report 2019: Leaving No One Behind. UNESCO, Paris

68. Xiong Y (2009) The Simulated Columns Tests on the Nitrogen Transformation and Biodegradation during the Reclaimed Water Infiltration Through the Vadose (Mater). China University of Geosciences 
(Beijing), Beijing

69. Yang L, He J, Liu Y, Wang J, Jiang L, Wang G (2016) Characteristics of change in water quality along reclaimed water intake area of the Chaobai River in Beijing, China. Journal of Environmental Sciences Sustainable Water Environment Water Use 50:93-102.

https://doi.org/10.1016/j.jes.2016.05.023

70. Yu Y (2013) A Research of the Impact of Reclaimed Water as Scenic Water on the Groundwater in Water Channel -A Case Study of Beijing Segment of Chaobai River (Doctor). The University of Chinese Academy of Sciences

71. Yu Y, Song X, Zhang Y, Zheng F, Liu L (2016) Impact of reclaimed water in the watercourse of Huai River on groundwater from Chaobai River basin, Northern China. Front Earth Sci 11:643-659. https://doi.org/10.1007/s11707-016-0600-5

72. Yuan R, Wang M, Wang S, Song X (2020) Water transfer imposes hydrochemical impacts on groundwater by altering the interaction of groundwater and surface water. J Hydrol 583:124617. https://doi.org/10.1016/j.jhydrol.2020.124617

73. Zhang N, Liu X, Liu R, Zhang T, Li M, Zhang Z, Qu Z, Yuan Z, Yu H (2018) Influence of reclaimed water discharge on the dissemination and relationships of sulfonamide, sulfonamide resistance genes along the Chaobai River, Beijing. Front Environ Sci Eng 13:8. https://doi.org/10.1007/s11783019-1099-2

74. Zhang R, Zhang Y, Liu L, Wang Y, Song Z, Wang X, Liu C, Li Y, Meng W, Zhou Y, Sun D, Qi F (2020) Occurrence and risk assessment of heavy metals in an urban river supplied by reclaimed wastewater. Water Environment Research wer.1341. https://doi.org/10.1002/wer.1341

75. Zhang Y, Wang J, Jing J, Sun J (2014) Response of groundwater to climate change under extreme climate conditions in North China Plain. J Earth Sci 25:612-618. https://doi.org/10.1007/s12583014-0443-5

76. Zhang Y, Yu Y (2021) Evaluating the impact of percolated reclaimed water from river-channel reservoir on groundwater using tracers in Beijing, Northern China. Environ Earth Sci 80:138. https://doi.org/10.1007/s12665-021-09449-1

77. Zheng C, Hill MC, Cao G, Ma R (2012) MT3DMS: Model Use, Calibration, and Validation. Transactions of the ASABE 55:1549-1559. https://doi.org/10.13031/2013.42263

78. Zheng F (2012) Case Study on Effects of Reclaimed Water Use for Scenic Water on Groundwater Environment in Chaobai River (Doctor). China University of Geosciences (Beijing)

79. Zheng F, Liu L, Li B, Yang Y, Gou M (2015) Effects of Reclaimed Water Use for Scenic Water on Groundwater Environment in a Multilayered Aquifer System beneath the Chaobai River, Beijing, China: Case Study. J Hydrol Eng 20:B5014003. https://doi.org/10.1061/(ASCE)HE.19435584.0001052

80. Zhu Z, Dou J (2018) Current status of reclaimed water in China: an overview. Journal of Water Reuse Desalination 8:293-307. https://doi.org/10.2166/wrd.2018.070 

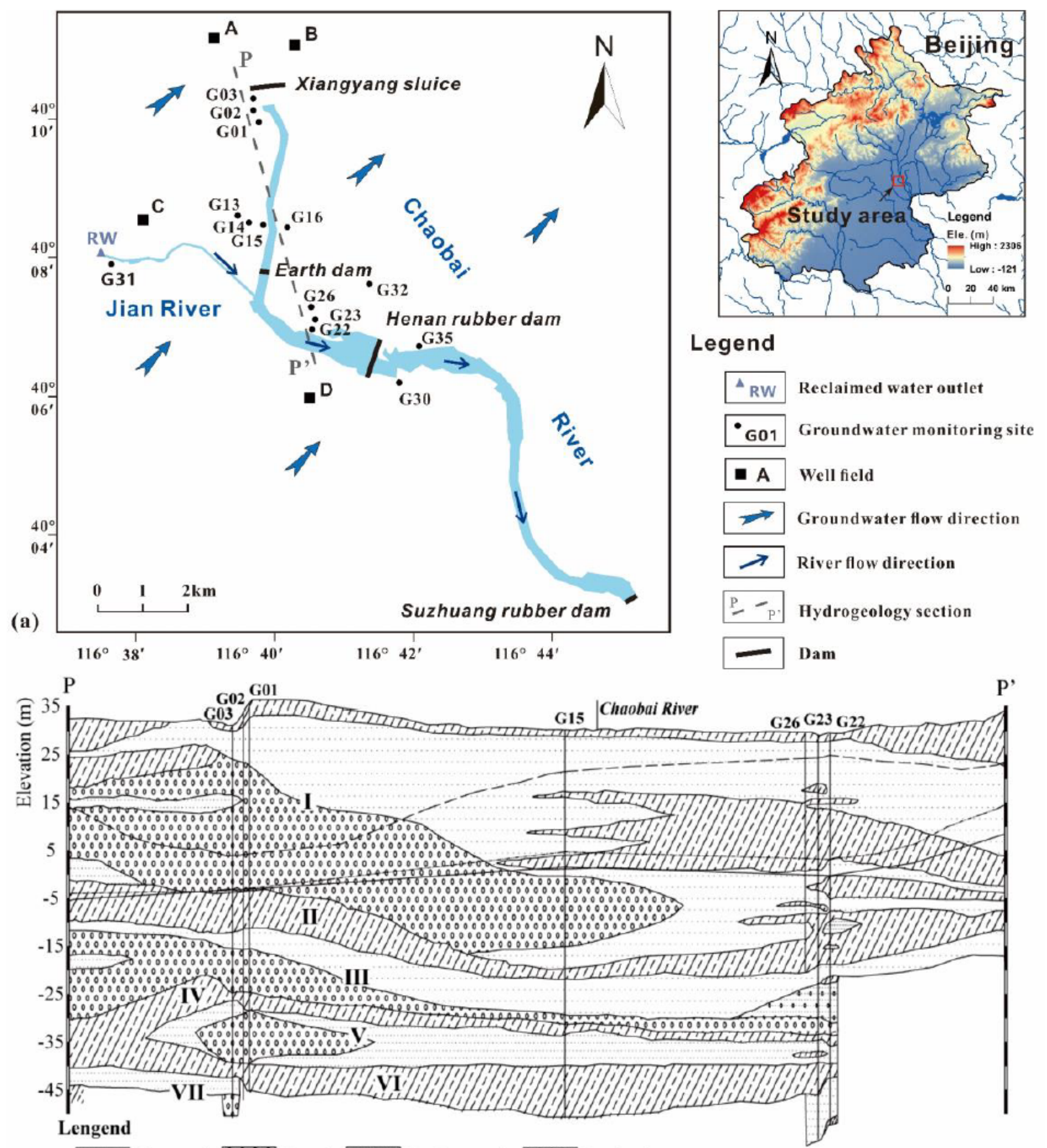

$\square$ Fine sand $\because \because \%$ Gravel $\because \because$ Sandy gravel $\quad \because Z$ Sandy clay

(b)

Groundwater table of I Groundwater level of III $\quad$ Groundwater level of V

\section{Figure 1}

Location map showing (a) water sampling sites, well fields in the study area, and (b) hydrogeological cross-section along P-P' from north to south (modified from Zheng et al., 2015). I refers to the unconfined aquifer in this study, and confined aquifers refer to III, $\mathrm{V}$, and $\mathrm{\nabla} . \mathrm{\nabla}, \mathrm{Z}$, and $\mathrm{Q}$ correspond to the aquitards. 

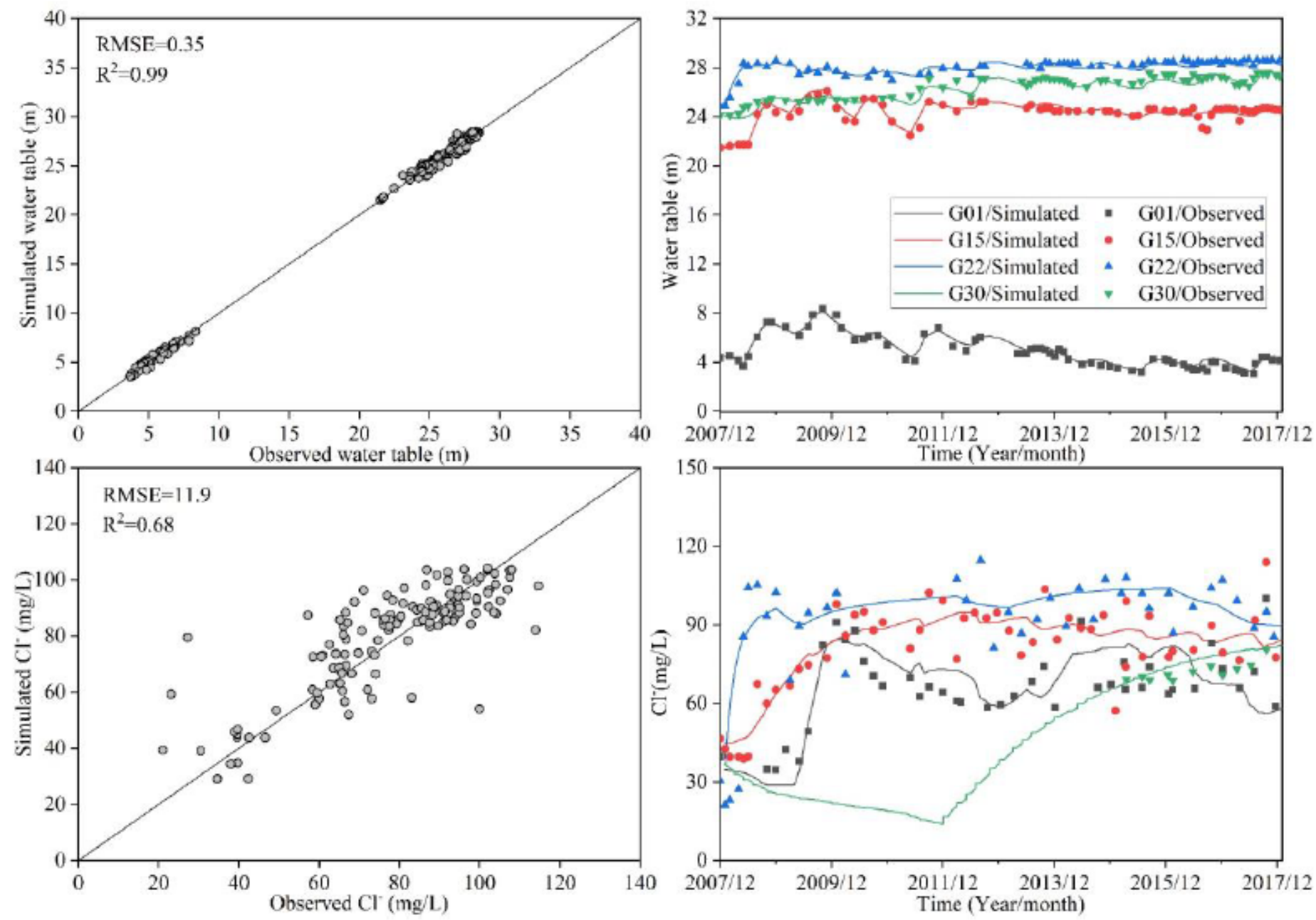

Figure 2

(a) Simulated versus observed results for groundwater tables in the unconfined aquifer, (b) comparison between the observed and simulated monthly groundwater tables for four typical observations, (c) Simulated versus observed $\mathrm{Cl}$ - concentration in the unconfined aquifer, (d) comparison between the observed and simulated monthly $\mathrm{Cl}$ - concentration for four typical observations during calibration and validation periods in the study area 

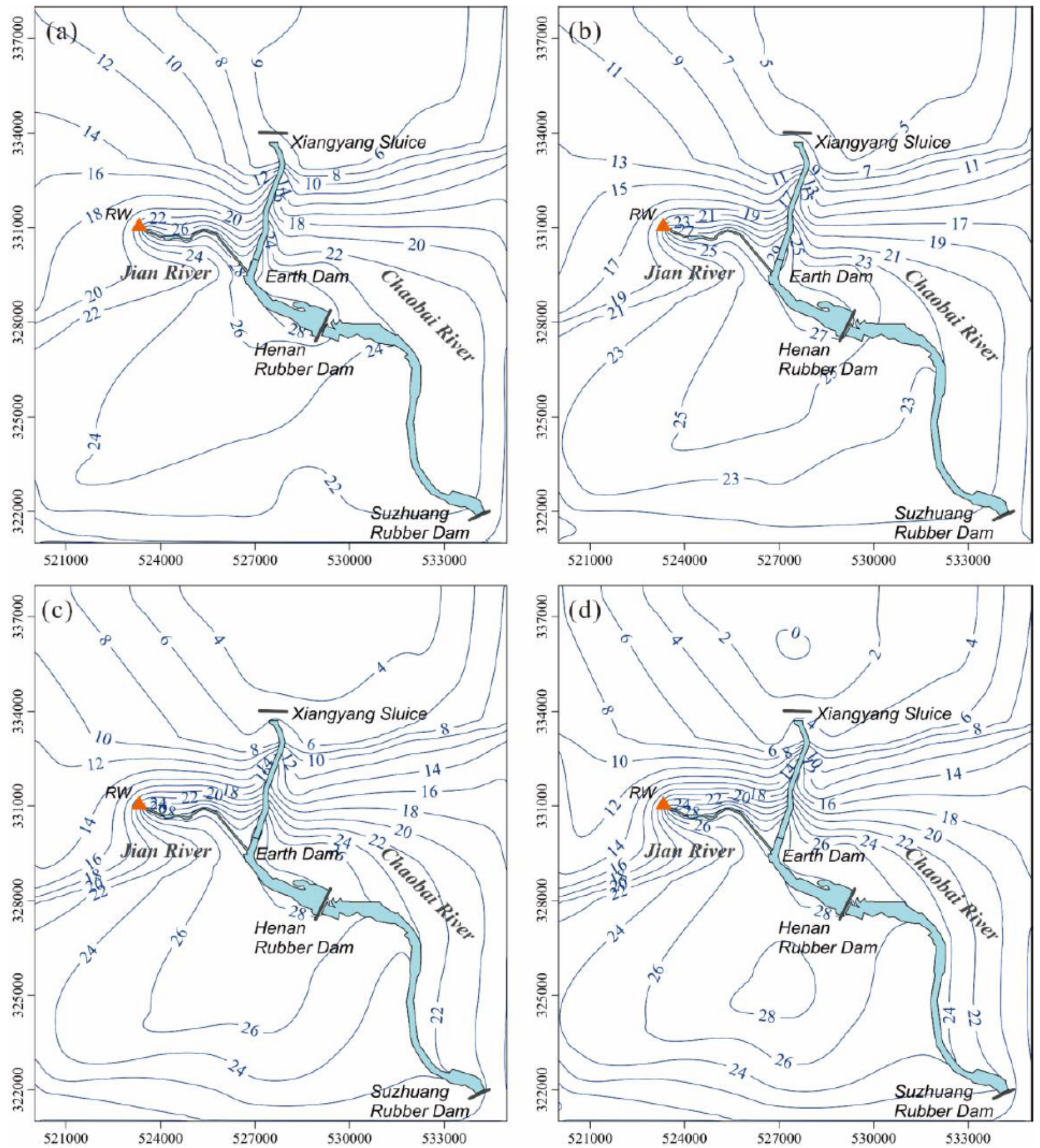

Figure 3

Distribution of the simulated groundwater table contours (unit: $m$ ) in the unconfined aquifer at the end of (a)2008, (b)2009, (c) 2012, and (d) 2017 after the RW restoring river channel (the coordinate system is the Beijing local coordinate system) 

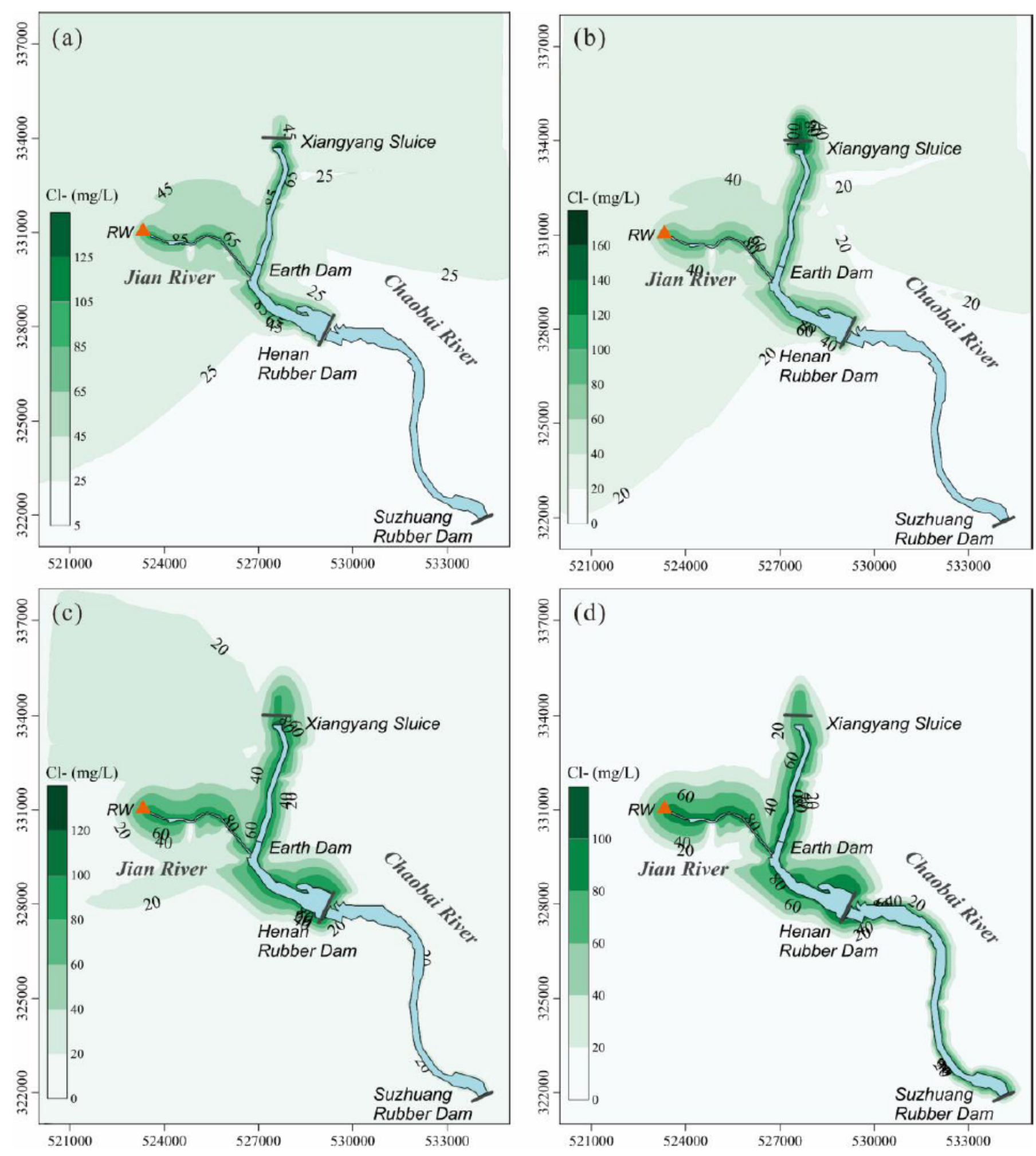

\section{Figure 4}

Distribution of the simulated $\mathrm{Cl}$ - concentrations in the unconfined aquifer at the end of 2008 (a), 2009 (b), 2012 (c), and 2017 (d) after RW restoring the river channel 


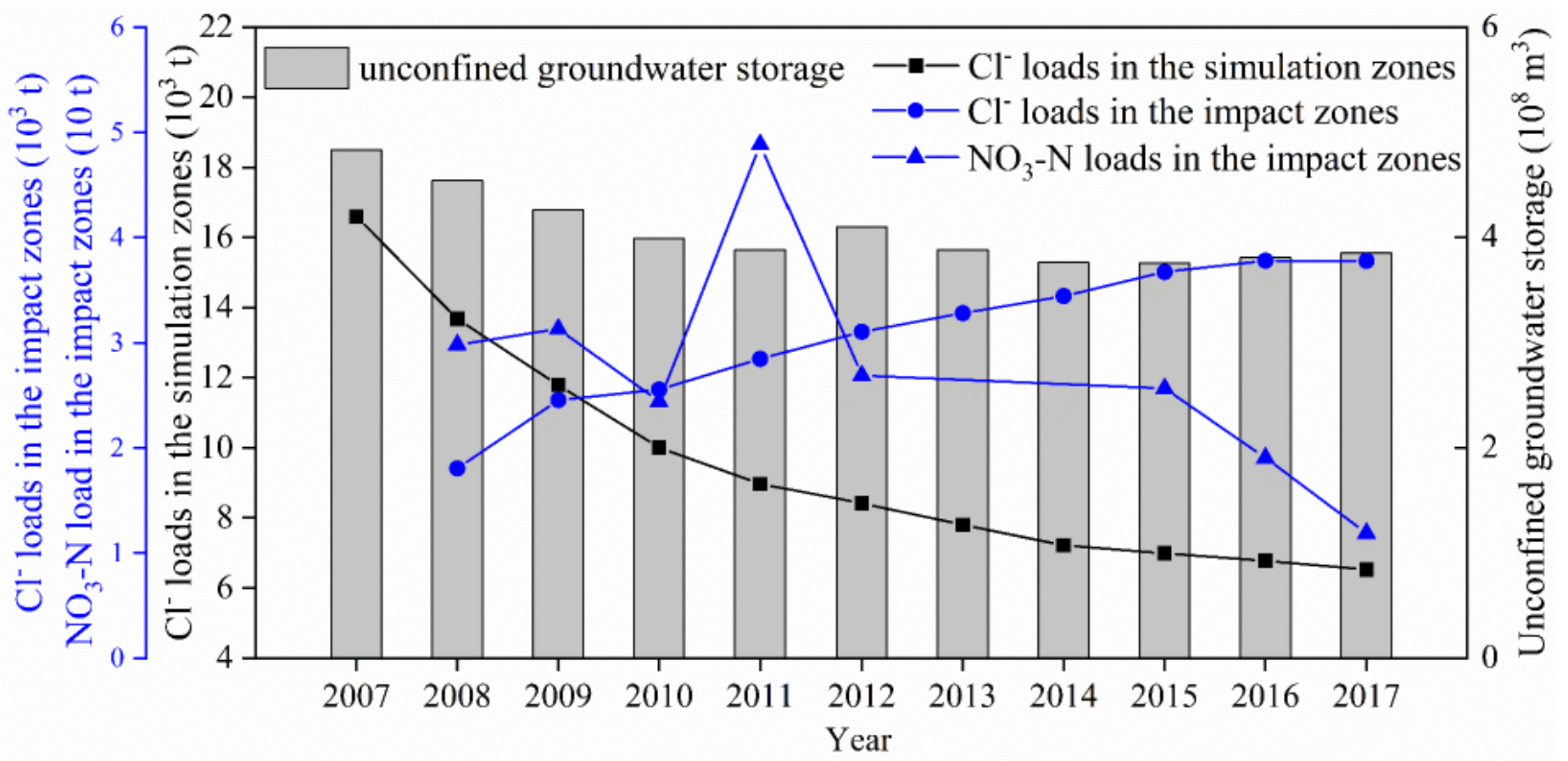

Figure 5

Variations of the unconfined groundwater storage, $\mathrm{Cl}$ - loads in the model area, $\mathrm{Cl}$ - loads, and NO3-N loads in the affected zones 

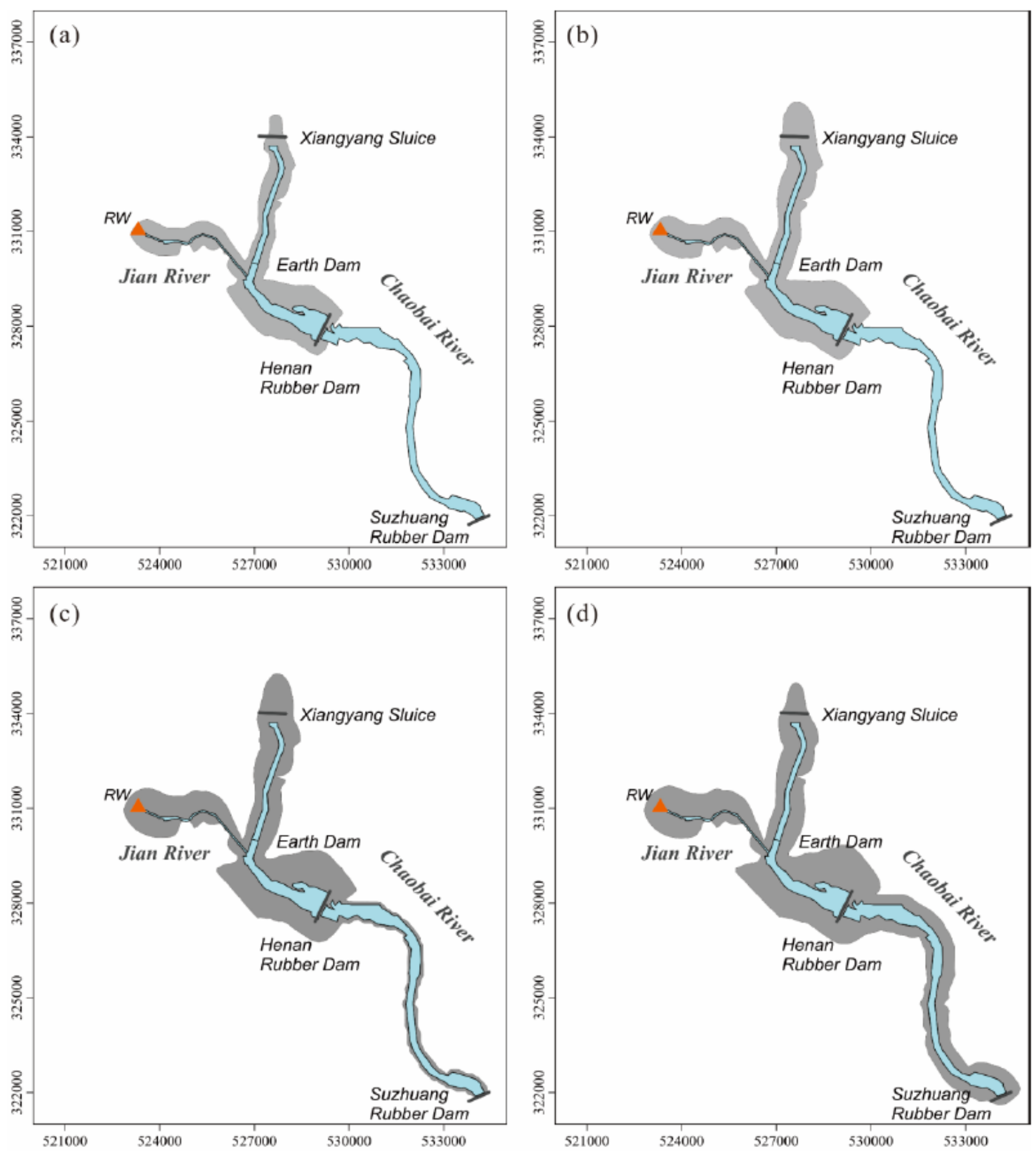

\section{Figure 6}

The zones affected by RW for the unconfined aquifer (grey area) at the end of 2008 (a), 2009 (b), 2012 (c), and 2017 (d) after RW restoring the river channel

\section{Supplementary Files}


This is a list of supplementary files associated with this preprint. Click to download.

- SupplementaryMaterials.docx 